\title{
Re-Designing Open Data 2.0
}

\author{
Alon Peled \\ Department of Political Science, The Hebrew University of Jerusalem, Mount Scopus, Israel, alon.peled@post.harvard.edu, \\ +(972)-54-628-26-21
}

\begin{abstract}
Since 2009, eighty-one countries subscribed to President Obama's Open Government program including its dominant Open Data (OD) component. Do OD 2.0 plans address the problems detected during the first generation of this program (2010-2012)? If not, how can these plans be improved? The article is a review of the main lines of criticism of the original OD program based on lessons learned worldwide. OD1.0 suffered from bad design, flawed execution, and adverse consequences. $O D 2.0$ plans fail to address the critical flaws of the first $O D$ program. The analysis of OD 1.0 reveals two primary lessons for converting OD 2.0 into a more focused and effective openness program: OD 2.0 architects must consider agencies' data release strategies, and avoid creating a transparency "policy bubble". Numerous countries followed the path of the original American OD program; therefore, the future of this program will have an impact on bureaucracies worldwide.
\end{abstract}

Keywords: Open Data, Open Government, Information Technology, Transparency, Bureaucratic Politics

D uring April, 2012, twenty-two American federal departments and agencies published plans for "Open Government 2.0" as required by the Open Government Directive (OGD) of December 2009. What were the main problems of the OD program worldwide? Do OD 2.0 plans address the problems detected during the first generation of this program (2010-2012)? If not, how can these plans be improved?

The article argues that OD 2.0 plans fail to address critical flaws of the OD 1.0 program. The article identifies and categorizes the main lines of criticism of the OD 1.0 program based on lessons learned worldwide. It is found that OD 1.0 suffered from bad design, flawed execution, and adverse consequences. The OD 1.0 analysis also reveals two lessons regarding agencies' data release strategies and the danger of a transparency "policy bubble", the article proposes concrete ideas for re-designing OD 2.0 to create a more focused and effective program.

President Obama launched the OD campaign in 2009. Since then, eighty-one countries subscribed to the Open Government program including its dominant OD component. Therefore, the future of the American OD program is important for efforts to improve government transparency worldwide.

The task of assembling, sorting, and categorizing hundreds of globally published OD 1.0 sources was a key research challenge. OD commentators publish important insights in non-traditional forums including blogs, web pages, and newspaper stories as well as in more traditional sources such as scholarly books and journal articles. The painstaking methodological effort paid off. The article presents concrete lessons from the $O D 1.0$ experience that will be useful to designers of $O D$ 2.0 .

It is important, however, to remember that OD is a new research field. Little systematic OD research has been performed to date (Zuiderwijk, Janssen, Choenni, Meijer, \& Alibaks, 2012, p. 169). Evidence of the economic, social, and democratic impact of OD programs is still "immature or lacking" (Huijboom \& Van den Broek, 2011, p. 10). OD research reports mainly include conceptual arguments, anecdotes, and technological discussions (Janssen, Charalabidis, and Zuiderwijk 2012, p. 3). OD supporters argue that "bottom-up demands for OD are mounting everywhere" (Fioretti, 2012, p. 2). Critics respond that neoliberal politicians have manipulated OD to mobilize public 
pressure to expand governmental services outsourcing (Bates, 2012, p. 7; Longo, 2011, pp. 4446). Yet, proponents and critics alike use little systematic quantitative analysis to substantiate their arguments as evidenced by the analysis below. Therefore the purpose of this article is to sketch the main lines of critique leveled against the original OD program, and suggest future directions for OD 2.0. The OD criticism below is best viewed as a set of hypotheses that are yet to be supported by rigorous empirical evidence.

\section{Transparency and Open Data Defined}

Transparency is openness to public scrutiny as defined by the rights and abilities of organizations and individuals to access government information and information about government. $\mathrm{OD}$ is the requirement that governments release authoritative, high quality, complete, and timely data on the Web in a downloadable, non-proprietary, and license-free format. The main OD argument is that governments are merely custodians of the information they collect, and that if this information is released to the public, communities of web developers and visionary thinkers will emerge to most effectively utilize the data, as happened with Code for America and the Sunlight Foundation in the United States (US) and the Open Knowledge Foundation in Britain (MayerSchonberger \& Cukier, 2013, pp. 116-117).

OD programs are intended to revitalize the economy and empower citizens to engage government (Bannister \& Connolly, 2011; Halonen, 2012; Harper, 2011; Van Den Broek, Kotterink, Huijboom, Hofman, \& Van Grieken, 2011). The OD movement relies on three assumptions: (1) politicians will agree to cede control over some information; (2) agencies will release data; and (3) citizens will use the published data. Critics argue that evidence does not support these assumptions (Janssen, Charalabidis, and Zuiderwijk, 2012, p. 3).

\section{President Obama's Open Government Blitzkrieg Campaign}

While campaigning in 2008, Obama promised to reverse the post 9/11 "retreat from openness." Between election-day and inauguration-day, the Obama-Biden transition crew commissioned a team to prepare the Open Government campaign. This team identified organizations that were willing to support a transparency agenda. President-elect Obama aimed to establish an "unprecedented level of openness in Government" and allies were "called to arms" (Millar, 2011).

President Obama then unleashed a blitzkrieg openness campaign. On his first full day in office (January 21 2009), at the height of the worst economic crisis America had experienced since the Great Depression, Obama signed three memorandums and two executive orders. Four of these five documents promoted open government (White House, 2009). Washington's government officials were invited to provide the administration with direct input (instead of commenting via their agencies). Within months of the new administration Vivek Kundra was appointed the first-ever federal Chief Information Officer ( $\mathrm{ClO})$, and an array of Open Government sites were launched: www.recovery.gov (to track taxpayer funds), eRulemaking (to encourage agencies to use Information Technology (IT) in rulemaking processes), and the IT Dashboard site (to track federal spending of IT dollars). The administration continually showcased Open Government innovation stories (Millar, 2011).

On May 21 2009, a team headed by the ClOs of both the Department of the Interior (DOI) and the Environment Protection Agency (EPA) launched www.data.gov (OMB, 2009), as the premier web publishing location for the most important federal datasets. On December 82009 the Office of Management and Budget (OMB) published the OGD. Agencies were instructed to publish at least three high-value datasets (datasets not previously made available or published in a downloadable and open format) (OMB 2009), to continually make new datasets available to the public (McDermott, 2010, p. 402), and to show concrete progress every fifteen to thirty days. On June 1, a White House report announced the success of the new OD initiative (Schuman, 2009; Trudeau, 2009; Wonderlich, 2011). 
Governments worldwide quickly adopted OD principles. Brown, the British Prime Minister launched his "Making Public Data Public" campaign in March 2010, shortly after the British OD site became operational. In April 2010, the World Bank launched an OD portal. Germany launched its OD project at the end of 2010. Denmark unleashed its own "Basic Data" campaign in October 2012. The European Commission launched an OD portal at the end of December 2012 (Jalote, 2012). The American OD site displays the flags of forty-two countries and four institutions (the UN, the World Bank, the OECD, and the EU) that subscribe to the OD movement. Scholars explained how OD lowered the cost of internal governmental operations. The media highlighted how OD fought corruption and helped the economy. Police crime maps and comparative school performance tables attracted tens of millions of visits. OD supporters claimed that the cost of releasing data is negligible and the benefits are limitless (Berners-Lee, 2010, 2012; Bertot, Jaeger, \& Grimes, 2010; A. Davies \& Lithwick, 2010; T. Davies, 2013; Eaves, 2010; Noveck, 2012; Tinati, Carr, Halford, \& Pope, 2012). On the 3rd anniversary of the American OD portal (May 21 2012), the USA General Services Administration (GSA) in partnership with India's National Informatics Centre produced an open source product called Open Government Platform (OGPL) so that other countries could copycat the American example.

\section{OD 1.0: Bad Design, Flawed Execution, and Adverse Consequences}

In practice, the OD program suffered from bad design, flawed execution, and adverse consequences as presented in Figure 1.0 below and explained in the following three sections:

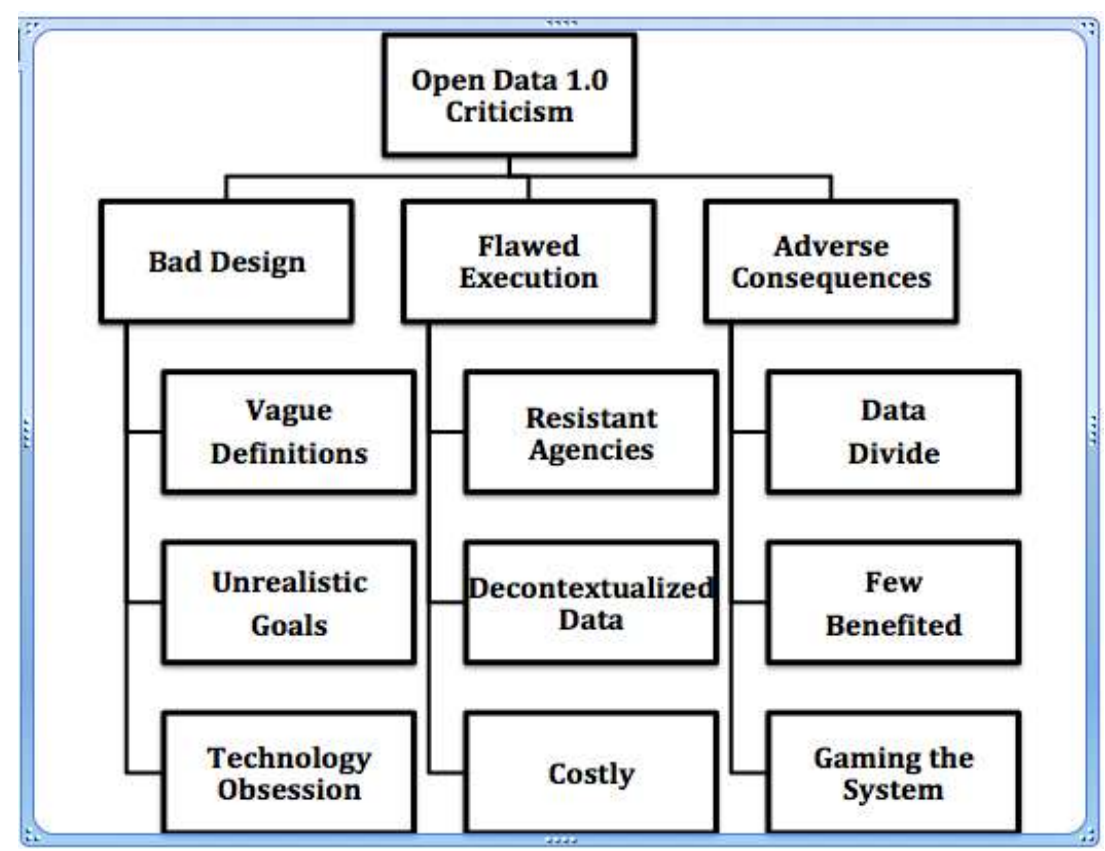

Figure 1: Open Data 1.0 Criticism

\subsection{Bad Design}

Lack of a clear definition of OD led to it becoming a vogue but vague concept; a catch-all phrase with amorphous meaning (Yu \& Robinson, 2012). To some people, the OD concept meant the release of downloadable data. Others interpreted OD to imply the release of data to boost the economy. Still, others considered $\mathrm{OD}$ to be a program designed to release information about the government. This vague definition fragmented the OD community (Hall, Shadbolt, Tiropanis, OHara, \& Davies, 2012; Schellong \& Stepanets, 2011; Yu \& Robinson, 2012). Noveck admitted that Open Government and OD definitions were confusing. She therefore proposed to re-focus the Open Government program with its OD component on taking advantage of the know-how and 
entrepreneurial spirit of those outside government institutions to work together with those inside government to solve problems (Noveck, 2011).

The Obama Administration used the vague OD definition to feature its catch-all OD project, and deflect attention from other faltering electoral openness programs. International organizations similarly used the vague OD label to highlight government openness. The Open Government Partnership (OGP) accepts any country based on a vague pledge to become more open (Yu \& Robinson, 2012). OGP members include countries defined as non-free or as partially-free by the Freedom House. The American OD web site also lists non-free and partially-free countries as OD countries. Country offerings are often sparse, for example Hong Kong "qualifies" as an OD country based on 32 datasets released by eight agencies (http://www.gov.hk/en/theme/psi/datasets).

OD 1.0 design was hindered by an unrealistic goal of maximizing transparency. Most OD proponents highlight the goal of maximum transparency to strengthen accountability, build trust, and tap into the public's collective intelligence. Compelled to live in glasshouses, bureaucratic behavior is affected by a culture of surveillance. Government officials cease to dissent, refer all decisions upwards, and adopt defensive thinking and blame avoidance strategies. Rather than speaking openly to those in power, government officials learn to cover-up and to self censor their advice (Bannister \& Connolly, 2011; Coglianese, 2009; Prat, 2006). The unrealistic and limitless goals of the OD 1.0 program alarmed government officials who were wary of such absolute transparency.

A third design flaw was the focus on technology as an indicator of transparency (Bass et al., 2010; Gurstein, 2011a). OD architects constructed glitzy websites but agencies could not keep up with the fast advent of web technology. Agencies often recreated a complex, inefficient organizational structure on the Web. A survey of seventy-five European local government web sites revealed that these sites reflected present service delivery patterns rather than transforming them. American agencies struggled with tough legal obstacles: the average federal web designer must comply with twenty-four different regulatory regimes (Pina, Torres, \& Royo, 2007, 2010; Robinson, Yu, Zeller, \& Felten, 2009).

In addition, OD's technology-focus may have deflected attention from the Right To Information (RTI) program. Ninety countries have adopted RTI legislation since the birth of the RTI movement in Sweden in 1766. Scholars hypothesized that OD may distract agencies from supporting RTI initiatives (T. Davies, 2013, pp. 4-5; K. Janssen, 2012, pp. 1-2). However, scholars have provided only anecdotal evidence to support the claim that US agencies have seemingly embraced OD while increasingly evading Freedom of Information (FOI) requests (Horner, 2012; Rosenberg, 2013).

\subsection{Flawed Execution}

In the US, the OGD gave agencies discretion to decide what data to publish and to evaluate their own performance; this allowed agencies to passively resist the OD program. Many agencies did not set openness deadlines for themselves or publish performance data; others refused to share data release plans; or did not live up to the goals that they themselves created. Not surprisingly, most agencies that assessed their own performance awarded themselves the highest compliance ranking (The White House, 2010; Wonderlich, 2011).

Most agencies reluctantly joined the US OD program. In mid 2011, 172 American agencies participated in the program; yet, only three agencies (the CENSUS, the US Geological Survey (USGS), and the National Oceanic and Atmospheric Administration (NOAA)) uploaded about 99\% of the content. The average participating agency had not returned to www.data.gov for 222 days since its last data.gov transaction (Peled, 2011). European agencies, too, reluctantly participated in OD programs and dumped volumes of purposeless raw data into cyberspace (Public Accounts Committee, 2012; Van Den Broek, Kotterink, Huijboom, Hofman, \& Van Grieken, 2011). In Britain, Estonia and Denmark certain agencies refused to free data because their income was partially dependent on data sales (Public Accounts Committee, 2012; Van Den Broek, Kotterink, Huijboom, Hofman, \& Van Grieken, 2011). 
Scholars explained that agencies refused to cooperate with OD programs because they derived income from data sales. Other scholars suggested that agencies refused to free datasets because these datasets are 'bargaining chips' in inter-agency relationships. A third group of scholars argued that agencies manipulate their closely held datasets to convince legislatures to grant them budgets. In addition, OD legislation compelled agencies to employ external consultants. Senior government IT officials might have been reluctant to delegate to consultants the politically sensitive job of deciding which datasets to release to the public (Peled, 2000). So, the OD program offered agencies a 'bad deal': Politicians received public approval for 'freeing data' while agencies were expected to free valuable datasets and undertake the time-consuming job of preparing them for release. Agencies therefore minimized their OD involvement (Harper, 2012; Peled, 2011; Van Den Broek, Kotterink, Huijboom, Hofman, \& Van Grieken, 2011).

Another execution problem was the de-contextualization of data. Data wrapped in context and traceable to its sources is a record. Records are the blood cells of governmental work. Noveck wrote: "the right of transparency is eviscerated by the practical inability of all but a handful of professionals to make sense of information" (Noveck, 2009, p. 124). But the OD program divorced datasets from their source records, thus converting useful records into useless datasets (Bass et al., 2010; Thurston, 2012). The EPA maintains context-rich Toxic Release Inventory (TRI) records on its web site, which were sliced and diced into numerous, context-free datasets and uploaded to www.data.gov. In addition, the OGD did not prioritize what data to release first (Harper, 2011), and did not establish mechanisms for citizens to verify data's accuracy, completeness, and authenticity (Cole, 2012; T. Davies \& Bawa, 2012; Thurston, 2012). Agencies released voluminous and meaningless datasets; repackaged data goods previously published elsewhere; and did not indicate if released datasets were previously available. The data lacked descriptions and, sometimes, datasets could not be downloaded or opened. Agencies did not offer mechanisms to report about data problems; nor did agencies provide explanation for the removal of released datasets (Bass et al., 2010).

Finally, OD architects did not consider the cost of 'freeing' data. Kundra argued that the government spends billions of dollars on "armies of consultants, a fragmented infrastructure, and customized, one-off applications" and that OD citizen-developers "can do more for less" (Kundra, 2011). Yet, agencies had to hire staff to understand new legislation, adjust data to new standards, train employees, and improve data quality. Agencies also converted hand written and verbal data into digital records and integrated non-compatible data streams to prepare data for release. These activities were costly and not included in the agencies' budgets (Bannister \& Connolly, 2011; Cole, 2012; Schellong \& Stepanets, 2011; UK Comptroller and Auditor General, 2012). A recent study based on interviews with 155 senior US federal IT officials revealed that these officials are concerned about the cost of adjusting their records management programs to the demands of the OD program (Biddick \& Kash, 2013).

\subsection{Adverse Consequences}

The OD program did not decrease the information divide between developed and developing countries. Developed states have good data collection mechanisms operated by skilled government officials. Developing countries lack such officials and their public data is often incomplete or misleading. In developing bureaucracies citizens usually neither contribute to nor participate in efforts to use data. Data seekers must navigate a bureaucratic maze after data is released. OD helped developed countries to use their public data better while offering little to developing countries (A. Davies \& Lithwick, 2010; T. Davies, 2013; Gurstein, 2012; B. Raman, 2012; N. V. Raman, 2012; Thurston, 2012). For example, in November 2012, Tim Berners-Lee announced the birth of Ghana's OD portal (http://data.gov.gh) after two years of planning, but almost one year later Ghana features the same 122 raw datasets, one application, no high value datasets, and no participating agencies on its US-style OD site (Berners-Lee, 2012). 
The OD program benefited limited stakeholders; it empowered the already empowered few such as corporations and software developers who jointly possess the funds and expertise to integrate data (Cole, 2012; Gurstein, 2011a; K. Janssen, 2012; Mayer-Schönberger \& Zappia, 2011). Life science corporations hired software developers to link and analyze datasets related to medical information that they could not previously access. Wealthy landowners hired software developers to exploit released data. In effect, OD provided a tax-free subsidy to wealthy corporations that no longer needed to pay for data (Bates, 2012; T. Davies, 2011, 2013; Feldman, 2011; Gurstein, 2011b). Neoliberal politicians manipulated OD to mobilize public pressure to expand the outsourcing and marketization of governmental services (Bates, 2012; T. Davies, 2013; Dunleavy, Margetts, Bastow, \& Tinkler, 2006; Halonen, 2012; Longo, 2011).

The OD program did not empower citizens and government officials. Sometimes, government officials had to purchase back their own data from private corporations (Bates, 2012). Citizens' mistrust of government grew as the media published OD evidence regarding alleged waste in government. Only $1 \%$ of all www.data.gov visitors have downloaded a dataset. Likewise, the United Kingdom (UK) Comptroller discovered that $80 \%$ of all visitors to www.data.gov.uk left the site without downloading data (Bannister \& Connolly, 2011; T. Davies, 2010, 2011; Fioretti, 2012; K. Janssen, 2012; McClean, 2011; Peled, 2011; The White House, 2012).

Scholars suggested that a related adverse consequence of OD is that it leads to information overload that confuses citizens. Evans and Campos described citizens' task of sorting out the relevance and reliability of released data as a confusing "herculean task" (2013, p. 172). Confusion, in turn, bred mistrust. Citizens' mistrust grew as the media published OD evidence, that citizens could not verify on their own, regarding governmental waste. For example, in May 2010, the UK Treasury published the Combined Online Information System (COINS) data. This data was so voluminous and poorly documented that citizens had to rely on the BBC and the Guardian for its interpretation (these media outlets hired developers to decipher the data) (McClean, 2011, pp. 8-9).

Finally, proponents assumed that people would use OD to "do wonderful things" (Berners-Lee, 2010). Yet, in practice, individuals and institutions learned how to "game the [OD] system." Real estate agents used crime maps to lock urban neighborhoods plagued by crime into their current difficult state. Schools learned how to manipulate performance tables to attract the 'right students.' Life-science corporations gamed the system to gain access to unidentifiable but sensitive medical records. The media manipulated data to enhance corruption allegations (Bannister \& Connolly, 2011; A. Davies \& Lithwick, 2010; T. Davies, 2011; Fioretti, 2012; McGinnes \& Elandy, 2012).

\section{OD 2.0 Plans: More of the Same}

At the beginning of 2011, the US OD architects left office. In February, Noveck departed her post as the Deputy Chief Technology Officer of the White House. Kundra resigned as CIO in June (Wadhwa, 2011). Still, the White House claimed that the OD program contributed substantial and measurable transparency gains (The White House, 2012). Kundra claimed that the OD program saved $\$ 3$ billion before the economic crisis forced the Government to cut the OD budget. Noveck claimed that OD created a "community of innovators across the executive branch" (Millar, 2011). However, OD 1.0 problems surfaced long before the program's budget was slashed.

Politicians' enthusiasm for OD began to wane. President Obama did not address the transparency issue during his $2^{\text {nd }}$ inauguration (Rosenberg, 2013, p. 1). In Britain, David Cameron instructed agencies to release some datasets for public consumption but refrained from adopting all-or-nothing demands like his predecessor (Brown) of "Making Public Data Public." Mr. Clarke, the Australian Secretary of the Department of Resources, Energy and Tourism formally rejected a recommendation to license at zero price geo-spatial data to the entire public sector (Lawrence, 2011; Office of Spatial Policy, 2012).

In designing OD 2.0, agencies had no reason to change their behavior. In April 2012, agencies published OD 2.0 plans congratulating themselves for creating a "culture of openness." Similar to 
OD 1.0, OD 2.0 plans are technology-focused, and agencies proposed to set their own openness goals and self-measure their compliance (Bingham \& Foxworthy, 2012).

\section{Lessons from OD 1.0}

\subsection{Agencies' Data Release Strategies}

The analysis of OD 1.0 reveals two primary lessons for converting OD 2.0 into a more focused and effective openness program: OD 2.0 architects must consider agencies' data release strategies, and avoid creating a transparency "policy bubble". The disappointing performance of the global OD movement demonstrates that agencies are reluctant to release datasets for free. A closer analysis reveals that agencies strategize to either "hug" datasets that they can trade with other agencies, or "brand" datasets to secure public funding. British, American and European agencies that trade datasets with other agencies or sell them to the public, appeared to cooperate with OD programs whilst in fact "hugging" their valuable datasets by releasing very little data (UK Comptroller and Auditor General, 2012; Van Den Broek, Kotterink, Huijboom, Hofman, \& Van Grieken, 2011). Both British and American agencies believe that they hold ownership over their valuable datasets (Halonen, 2012).

In contrast to data "hugging" practices, other agencies adopted an information branding strategy of publishing large quantities of valuable datasets on $O D$ web sites and through other not-for-fee channels, to secure continued access to public funding. For example, when Google Earth appeared in 2005, NOAA began providing valuable spatial datasets free of charge to Google. NOAA's information branding strategy paid off; Google lost its appetite to develop competing datasets and the American Congress continues to fund the NOAA programs that generate these datasets.

OD 2.0 architects must accept that data is valuable to agencies and be aware of agencies' data release strategies in designing a more realistic OD program. Rather than threaten bureaucratic data ownership and treat government officials as an incompetent threat, an OD program can rally an existing cadre of reform-oriented government officials and ensure that data-release concerns are addressed (Kelman, 2004). Legislatures must provide a legal framework such as an OD Commons to determine who owns public data after its release. Legislatures must also direct the OD program to pursue activities that only the government can provide such as the construction of a Trusted Digital Repository (TDR). Norway successfully introduced legislation, technical standards, and architecture to expose public data that is complete, accurate, timely, and trustworthy (Robinson, Yu, Zeller, \& Felten, 2009; Thurston, 2012).

In an OD program that acknowledges the value of data, 'open' can no longer imply 'free.' Agencies will lose motivation to develop raw data into information if coerced to free the information at no cost. One solution is to reduce the cost of OD rather than release it for free. An American state, Georgia, has already done so. Similarly, the Finnish National Mapping and Cadastral Agency (NMCA) sells data to public entities for a minimal cost. The Swiss NMCA introduced a 'freemium' program that supports releasing some data cheaply to mobile users while collecting higher prices from those who want higher-resolution maps. These policies have provided more openness than the "everything-for-free" OD 1.0 promise (Economist, 2012; EuroGeographics, 2009, 2010).

\subsection{The Danger of a Transparency "Policy Bubble"}

The global OD 1.0 program mimicked the behavior of a policy bubble. A policy bubble is created when a euphoric atmosphere and over confidence characterize a new policy. It is focused on a simplistic, self-enforcing set of ideas, and is fueled by media frenzy. Policy bubbles are ubiquitous and, when they burst, they wreak havoc on an entire policy system. Historical examples include investment-mania in the British railway during the 1840s and the American Apollo Space Program. The OD program was accompanied by just such over-confidence and media hype. The Economist recently defined the actual achievements of the OD 1.0 program as more "rhetoric" than "reality" 
(Economist, 2012, p. 35).The bursting of the OD policy bubble would impact negatively the willingness of politicians, government officials, and the public to invest in future transparency programs (Gisler \& Sornette, 2010; Jones \& Baumgartner, 2005; Jones, Thomas, \& Wolfe, 2013; Levitin \& Wachter, 2011; Maor, 2012; Raafat, Chater, \& Frith, 2009; Shiller, 2005, 2012).

To avoid this fate, OD 2.0 must be a component of a wider transparency program. More modest OD architects will adopt minimal but realistic goals for the OD component of a larger transparency program focused on improving governmental services to citizens or improving information about regulated entities (Shkabatur, 2012). We can identify domains appropriate for OD and domains more suited to alternate transparency channels. For example, an OD program would effectively support the release of historical and infrastructure information but less effectively the release of planning and operational data. A FOI-type program might do better than OD to help citizens unravel sensitive information (Cameron, 2012; Clarke, 2010; Eaves, 2013; Halonen, 2012). OD may also work better at the local rather than the national level (T. Davies \& Edwards, 2012; Fioretti, 2012; Rath, 2012; Tolbert \& Mossberger, 2006).

A broader transparency program would tap into the range of existing OD innovations, and accept that genuine transparency is groomed over many years. Scientific, professional, and local communities have been nurturing OD channels years before the OD movement emerged. American agencies have initiated valuable OD channels: since October 1999, the US Social Security Administration (SSA) has been sending annual statements of benefits to eligible Americans; in 2002, twenty-five US agencies jointly created an online grants application web portal that provides information on over 1,000 grant programs (Cook, Jacobs, \& Kim, 2010; GAO 2011). Introducing transparency is a process that takes many years. The American National Archives and Records Administration (NARA)'s new declassification portal (2012), owes its success to a breakthrough made sixteen years earlier (OMB Watch, 2012a). Likewise, online sites such as www.foia.gov owe their existence to legislative battles to create the Freedom of Information Act (FOIA) in 1967 and the Electronic FOIA in 1996 (Braman, 2006).

A transparency program that avoids a policy bubble must place the issues of data quality and context at the center. Citizens and government officials must collaborate to identify errors in the data. Officials must retrieve published data using the same infrastructure made available to the public. Crowdsourcing techniques can add context to released data; with improved context, the threshold for using the data would be lowered (Fioretti, 2012; Halonen, 2012; Robinson, Yu, Zeller, \& Felten, 2009). Releasing high quality, context-rich data is expensive. Therefore, an effective OD program must search for the sweet spot: high quality information that can be released for a low data-integration cost and have a lasting impact on citizens' lives (Feldman, 2011; Kuk \& Davies, 2011; Public Accounts Committee, 2012; GAO, 2010; UK Comptroller and Auditor General, 2012). To control cost, an OD program must curb the appetite of IT vendors to pursue technological experimentation for its own sake (Heald, 2006; Hendler, 2010; Henry, 2009; OMB Watch, 2012b). Such a program must also adopt measures to ensure that it does not increase the gap between the "data haves" and the "data have-nots." Some OD expenditures could be invested in activities that reduce data gaps including training civic activists to convert raw data into useful information and increasing digital literacy (T. Davies, 2013; T. Davies \& Edwards, 2012; Gurstein, 2011a).

\section{Open Data: Too Much of a Good Thing?}

OD is a good thing but, as one scholar suggested, "it is possible to have too much of a good thing" (Coglianese, 2009, p. 530). Nam argued that governments are yet to develop strategies to convert e-government initiatives such as OD "from hype and rhetoric into hope and actual achievement" (2012, p. 365). A good OD strategy must begin with the realization that in some domains, OD can be an effective means to improve decision making and services to citizens; in other domains, OD does not help and could even do harm (such as having a chilling impact on the behavior of government officials). Reformers must take into account that data is valuable to agencies, and that transparency is a big task that requires the creation of multiple openness 
channels. A well-designed transparency program must cut to size the aspirations and goals of its OD component.

The overall merit of the OD program should not be judged entirely by the limited nature of its early version (OD 1.0, 2010-2012). OD 1.0 was an early experiment of a promising idea. Nonetheless, politicians must understand that an effective OD program requires time and patience to grow. Politicians promoted the OD 1.0 program aggressively, hoping to extract public relations benefits from its fast implementation. The results of this program were therefore mediocre. The key question is: will politicians agree to invest time and energy to promote a more modest and more effective OD 2.0 that is likely to yield less public relations gains but more high-value transparency?

\section{References}

Bannister, F., \& Connolly, R. (2011). The Trouble with Transparency: A Critical Review of Openness in e-Government. Policy \& Internet, 8(3), 1-30.

Bass, G., Brian, D., Fuchs, M., Schwartz, A., McDermott, P., Miller, E., \& Weismann, A. (2010). Letter Encouraging the Administration to Improve Its Open Government Efforts. Retrieved September 20, 2013, from http://www.pogo.org/our-work/letters/2010/gs-og-20100203.html?print=t

Bates, J. (2012). "This is what modern deregulation looks like": Co-optation and contestation in the shaping of the UK's Open Government Data Initiative. The Journal of Community Informatics, 8(2).

Berners-Lee, T. (2010). The year open data went worldwide. TedGlobal. Retrieved August 13, 2013, from http://www.ted.com/talks/tim_berners_lee_the_year_open_data_went_worldwide.html

Berners-Lee, T. (2012). Sir Tim Berners-Lee: Raw data, now! Retrieved August 13, 2013, from http://www.wired.co.uk/news/archive/2012-11/09/raw-data

Bertot, J. C., Jaeger, P. T., \& Grimes, J. M. (2010). Using ICTs to create a culture of transparency: E-government and social media as openness and anti-corruption tools for societies. Government Information Quarterly, 27(3), 264-271.

Biddick, M., \& Kash, W. (2013). 2014 Federal Government IT Priorities InformationWeek Government (pp. 1-33). Washington, D. C.

Bingham, L. B., \& Foxworthy, S. (2012, July 19 and 20). Collaborative Governance and Collaborating Online: The Open Government Initiative in the United States. Paper presented at the Converging and Conflicting Trends in the Public Administration of the US, Europe, and Germany, The German Research Institute for Public Administration Speyer (GRIP) and The School of Public and Environmental Affairs (SPEA) of Indiana University.

Braman, S. (2006). Change of State - Information, Policy, and Power. Cambridge, MA: The MIT Press.

Cameron, D. (2012). Letter to Government departments on opening up data. Retrieved September 20, 2013, from http://www.number10.gov.uk/news/letter-to-government-departments-on-opening-up-data/

Clarke, P. (2010). There's data, and there's data. Retrieved September 20, 2013, from http://paulclarke.com/honestlyreal/2010/06/theres-data-and-theres-data/

Coglianese, C. (2009). The Transparency President? The Obama Administration and Open Government. Governance: An International Journal of Policy and Administration, 22(4), 529-544.

Cole, R. J. (2012). Some Observations on the Practice of Open Data As Opposed to Its Promise. The Journal of Community Informatics, 8(2).

Cook, F. L., Jacobs, L. R., \& Kim, D. (2010). Trusting What You Know: Information, Knowledge and Confidence in Social Security. The Journal of Politics, 72(2), 397-412.

Davies, A., \& Lithwick, D. (2010). Government 2.0 and Access to Information: Recent Developments in Proactive Disclosure and Open Data in the United States and Other Countries. Retrieved September 20, 2013, from http://www.parl.gc.ca/Content/LOP/ResearchPublications/2010-15-e.pdf

Davies, T. (2010, Summer 2010). Open data, democracy and public sector reform. A look at open government data use from data.gov.uk. Social Science of the Internet. Retrieved September 20, 2013, from http://www.opendataimpacts.net/report/wp-content/uploads/2010/08/How-is-open-government-data-being-used-inpractice.pdf

Davies, T. (2011). Evaluating the Autumn Statement Open Data Measures. Retrieved September 20, 2013, from http://www.timdavies.org.uk/2011/12/02/3090/ 
Davies, T. (2013). How might open data contribute to good governance? In R. Jones-Parry \& A. Robertson (Eds.), Commonwealth Governance Handbook 2012/13: Democracy, development and public administration. London: The Commonwealth.

Davies, T., \& Bawa, Z. A. (2012). The Promises and Perils of Open Government Data (OGD). The Journal of Community Informatics, 8(2).

Davies, T., \& Edwards, D. (2012). Emerging Implications of Open and Linked Data for Knowledge Sharing in Development. IDS Bulletin, 43(5).

Dunleavy, P., Margetts, H., Bastow, S., \& Tinkler, J. (2006). New Public Management Is Dead—Long Live Digital-Era Governance. Journal of Public Administration Research and Theory, 16(3), 467-494.

Eaves, D. (2010). Case study: How Open data saved Canada \$3.2 Billion. Retrieved September 20, 2013, from http://eaves.ca/2010/04/14/case-study-open-data-and-the-public-purse/

Eaves, D. (2013). Access to Information is Fatally Broken... You Just Don't Know it Yet. Retrieved September 20, 2013, from http://eaves.ca/2011/03/30/access-to-information-is-fatally-broken-you-just-dontknow-it-yet/

Economist. (2012). The Best Disinfectant - Hopes Of "Open Government” Under Barack Obama Have Been Only Partly Fulfilled. Economist. Retrieved November 28, 2013, from http://www.economist.com/node/21555924

EuroGeographics. (2009). Business Interoperability Group (BIG) Meeting (December 7-8) - Minutes and Actions. Retrieved September 20, 2013, from http://www.eurogeographics.org/sites/default/files/20100115_BIG group meeting minutes and actions 7_8 December 2009_V2.0_SW.pdf

EuroGeographics. (2010). EuroGeographics Business Interoperability Group (BIG) Meeting (March 24-25th) - Minutes and Actions. Retrieved September 20, 2013, from http://www.eurogeographics.org/sites/default/files/20100730_BIGminutes_and_actionsMarch2010_V2 0_SW.pdf

Evans, A. M., \& Campos, A. (2013). Open Government Initiatives: Challenges of Citizen Participation. Journal of Policy Analysis and Management, 32(1), 172-185.

Feldman, S. (2011). OpenData - who profits? Retrieved September 20, 2013, from http://knowwhereconsulting.co.uk/opendata-who-profits/

Fioretti, M. (2012). Open Data: Emerging trends, issues and best practices - a research project about openness of public data in EU local administration. In G. Bottazzi (Ed.), Open Data, Open Society. Pisa: Laboratory of Economics and Management.

Gisler, M., \& Sornette, D. (2010). Bubbles everywhere in human affairs. In L. Kajfež-Bogataj, K. H. Müller, I. Svetlik \& N. Toš (Eds.), Modern RISC-Societies. Towards a New Framework for Societal Evolution (pp. 137-153). Wien: Edition echoraum.

Gurstein, M. B. (2011a). A Data Divide? Data "Haves" and "Have Nots" and Open (Government) Data. Gurstein's Community Informatics. Retrieved September 20, 2013, from http://gurstein.wordpress.com/2011/07/11/a-datadivide-data-\%E2\%80\%9Chaves\%E2\%80\%9D-and-\%E2\%80\%9Chave-nots\%E2\%80\%9D-and-open-governmentdata/

Gurstein, M. B. (2011b). Open Data: Empowering the Empowered or Effective Data Use for Everyone? First Monday. Retrieved September 20, 2013, from http://firstmonday.org/htbin/cgiwrap/bin/ojs/index.php/fm/article/view/3316/2764

Gurstein, M. B. (2012). Two Worlds of Open Government Data: Getting the Lowdown on Public Toilets in Chennai and Other Matters. The Journal of Community Informatics, 8(2).

Hall, W., Shadbolt, N., Tiropanis, T., OHara, K., \& Davies, T. (2012). Open data and charities. Retrieved September 28 , 2013, from http://eprints.soton.ac.uk/id/eprint/341346

Halonen, A. (2012). Being Open About Data: Analysis Of The UK Open Data Policies And Applicability Of Open Data. London: The Finnish Institute in London.

Harper, J. (2011). Government Spending Transparency: 'Needs Improvement' Is Understatement. CATO@LIBERTY. Retrieved September 20, 2013, from http://www.cato.org/blog/government-spending-transparency-needsimprovement-understatement

Harper, J. (2012). Is Government Transparency Headed for a Detour? CATO@LIBERTY. Retrieved September 20, 2013, from http://www.cato-at-liberty.org/is-government-transparency-headed-for-a-detour/

Heald, D. (2006). Varieties of Transparency. In a. D. H. C. Hood (Ed.), Transparency, The Key to Better Governance (pp. 25-43). Oxford: Oxford University Press.

Hendler, C. (2010). Report Card: Obama's Marks at Transparency U. Columbia Journalism Review. Retrieved September 20, 2013, from http://www.cjr.org/transparency/report_card.php

Henry, E. (2009). Obama Signing Friday Breaks Transparency Pledge. Retrieved October 12, 2010, from http://politicalticker.blogs.cnn.com/2009/05/20/obama-signing-friday-breaks-transparency-pledge/ 
Horner, C. C. (2012). The Liberal War on Transparency: Confessions of a Freedom of Information "Criminal". New York, NY: Threshold Editions.

Huijboom, N., \& Van den Broek, T. (2011). Open data: an international comparison of strategies. European Journal of ePractice, 12, 1-13.

Jalote, S. (2012). European Commission releases Open Data Portal. Retrieved February 16, 2013, from http://www.futuregov.asia/articles/2012/dec/31/european-commission-releases-open-data-portal/

Janssen, K. (2012). Open Government Data and the Right to Information: Opportunities and Obstacles. The Journal of Community Informatics, 8(2), 1-15.

Janssen, M., Charalabidis, Y., \& Zuiderwijk, A. (2012). Benefits, Adoption Barriers and Myths of Open Data and Open Government. Information Systems Management (ISM), 29(4), 258-268.

Jones, B. D., \& Baumgartner, F. R. (2005). The Politics of Attention: How government prioritizes problems. Chicago: University of Chicago Press.

Jones, B. D., Thomas, T., \& Wolfe, M. (2013). The Role of the Media in Policy Bubbles. Retrieved September 20, 2013, from http://www.policyagendas.org/sites/policyagendas.org/files/Jones_Policy_Bubbles_Talk_at_Stanford.pdf

Kelman, S. (2004). Changing Big Government Organizations: Easier than meets the eye? Faculty Research Working Papers Series. John F. Kennedy School of Government: Harvard University.

Kuk, G., \& Davies, T. (2011). The Roles of Agency and Artifacts in Assembling Open Data Complementarities. ICIS. Retrieved September 20, 2013, from http://eprints.soton.ac.uk/273064/1/Kuk\%2C Davies - 2011 - The Roles of Agency and Artifacts in Assembling Open Data Complementarities.pdf

Kundra, V. (2011). From Data to Apps: Putting Government Information to Work for You. The White House Blog. Retrieved August 13, 2013, from http://www.whitehouse.gov/blog/2011/05/20/data-apps-putting-government-information-workyou

Lawrence, V. (2011, October). Investigation into the Spatial Capability of Australia. Retrieved September 20, 2013, from http://www.ret.gov.au/Department/Documents/osp/Lawrence-Report_Final-2011-10.pdf

Levitin, A. J., \& Wachter, S. M. (2011). Explaining the Housing Bubble. Georgetown Law Journal, 100(4), 1177-1258.

Longo, J. (2011). OpenData: Digital-Era Governance Thoroughbred or New Public Management Trojan Horse? Public Policy and Governance Review, 2(2), 38-52.

Maor, M. (2012). Policy Overreaction. Journal of Public Policy, 32(3).

Mayer-Schonberger, V., \& Cukier, K. (2013). Big Data: A Revolution That Will Transform How We Live, Work, and Think. Boston, MA: Houghton Mifflin Harcourt.

Mayer-Schönberger, V., \& Zappia, Z. (2011). Participation and Power: Intermediaries of Open Data. Paper presented at the 1st Berlin Symposium on Internet and Society, Berlin, Germany. http://berlinsymposium.org/sites/berlinsymposium.org/files/participation_and_power.pdf

McClean, T. (2011). Not with a Bang but a Whimper: The Politics of Accountability and Open Data in the UK. American Political Science Association Annual Meeting. Retrieved September 20, 2013, from http://papers.ssrn.com/sol3/papers.cfm?abstract_id=1899790

McDermott, P. (2010). Building Open Government. Government Information Quarterly, 27, 401-413.

McGinnes, S., \& Elandy, K. M. (2012). Unintended Behavioural Consequences of Publishing Performance Data: Is More Always Better? The Journal of Community Informatics, 8(2).

Millar, L. (2011). Beth Noveck, Former US Deputy CTO In Interview. Asia Pacific FutureGov. Retrieved September 20, 2013, from http://www.futuregov.asia/articles/2011/mar/18/transparency-collaboration-and-participation-inter/

Nam, T. (2012). Citizens' attitudes toward Open Government and Government 2.0. International Review of Administrative Sciences, 78(2), 346-368.

Noveck, B. S. (2009). Wiki government: how technology can make government better, democracy stronger, and citizens more powerful. Washington, D. C: Brookings Institution Press.

Noveck, B. S. (2011). Defining Open Government. Cairns Blog. Retrieved September 28, 2013, from http://cairns.typepad.com/blog/2011/04/whats-in-a-name-open-gov-we-gov-gov-20-collaborative-government.html

Noveck, B. S. (2012). Demand a More Open Source Government. TedGlobal. Retrieved August 13, 2013, from http://www.ted.com/talks/beth_noveck_demand_a_more_open_source_government.html

Office of Management and Budget (OMB). (2009). Open Government Directive. Retrieved September 28, 2013, from http://www.whitehouse.gov/open/documents/open-government-directive

Office of Spatial Policy. (2012). The Australian Government Response to the Report by Dr Vanessa Lawrence CB on the Investigation Into the Spatial Capability of Australia. Retrieved September 20, 2013, from http://www.ret.gov.au/Department/Documents/osp/Response-to-Lawrence-Report-2012-04.pdf 
OMB Watch. (2012a). Scaling Up Transparency: New Approaches Could Yield Greater Openness. Retrieved September 20, 2013, from http://www.ombwatch.org/scaling-up-transparency

OMB Watch. (2012b). Updated Agency Plans Show Path toward Culture of Openness. Retrieved September 20, 2013, from http://www.ombwatch.org/node/12049

Peled, A. (2000). The politics of outsourcing: bureaucrats, vendors, and public information technology (IT) projects. Information Infrastructure \& Policy, 6(4), 209.

Peled, A. (2011). When Transparency and Collaboration Collide:The USA Open Data Program. Journal Of The American Society For Information Science And Technology [JASIST], 62(11), 2085-2094.

Pina, V., Torres, L., \& Royo, S. (2007). Are ICTs Improving Transparency And Accountability In The EU Regional And Local Governments? An Empirical Study. Public Administration, 85(2), 449-472.

Pina, V., Torres, L., \& Royo, S. (2010). Is E-Government Leading To More Accountable And Transparent Local Governments? An Overall View. Financial Accountability \& Management, 26(1), 3-20.

Prat, A. (2006). The More Closely We Are Watched, the Better We Behave? In a. D. H. C. Hood (Ed.), Transparency, the Key to Better Governance (pp. 92-103). Oxford: Oxford University Press.

Public Accounts Committee. (2012). Implementing the transparency agenda. Retrieved September 20, 2013, from http://www.publications.parliament.uk/pa/cm201213/cmselect/cmpubacc/102/10202.htm

Raafat, R. M., Chater, N., \& Frith, C. (2009). Herding in humans. Trends in cognitive sciences, 13(10), 420-428

Raman, B. (2012). The Rhetoric and Reality of Transparency: Transparent Information, Opaque City Spaces and the Empowerment Question. The Journal of Community Informatics, 8(2).

Raman, N. V. (2012). Collecting Data in Chennai City and the Limits of Openness. The Journal of Community Informatics, $8(2)$.

Rath, S. (2012). Data Template for District Economic Planning. The Journal of Community Informatics, 8(2).

Robinson, D., Yu, H., Zeller, W. P., \& Felten, E. W. (2009). Government Data and the Invisible Hand. Yale Journal of Law and Technology, 11, 160-175.

Rosenberg, L. (2013). A Decidedly Different Obama on Transparency. Sunlight Foundation. Retrieved September 20, 2013, from http://sunlightfoundation.com/blog/2013/01/22/a-decidedly-different-obama-on-transparency/

Schellong, A., \& Stepanets, E. (2011). Unchartered waters - the State of Open Data in Europe Public Sector Study Series. Wiesbaden, Germany.

Schuman, D. (2009). Open Government Directive Timelines. Sunlight Foundation (Blog). Retrieved September 20, 2013, from http://sunlightfoundation.com/blog/2009/12/08/open-government-directive-timelines/

Shiller, R. J. (2005). Irrational Exuberance. New York: Broadway Books.

Shiller, R. J. (2012). Bubbles without Markets. Retrieved September 28, 2013, from http://www.projectsyndicate.org/commentary/bubbles-without-markets

Shkabatur, J. (2012). Transparency With(out) Accountability: Open Government in the United States. Yale Law \& Policy Review, 31(1), 66

The White House. (2010). Open Government Initiative - Open Government Plan Evaluation Criteria. Retrieved September 20, 2013, from http://www.whitehouse.gov/open/documents/evaluation

The White House. (2012). The Obama Administration's Commitment to Open Government: A Status Report. Retrieved September 20, 2013, from http://www.whitehouse.gov/sites/default/files/opengov_report.pdf

The White House - Office of the Press Secretary. (2009). President Signs Two Executive Orders and Three Memorandums (Press Release). Retrieved August 13, 2013, from http://www.whitehouse.gov/the-press-office/statement-presssecretary-presidents-signing-two-executive-orders-and-three-memoran

Thurston, A. C. (2012). Trustworthy Records and Open Data. The Journal of Community Informatics, 8(2).

Tinati, R., Carr, L., Halford, S., \& Pope, C. (2012). Exploring the Impact of Adopting Open Data in the UK Government. Digital Futures 2012. Retrieved September 20, 2013, from http://eprints.soton.ac.uk/id/eprint/344808

Tolbert, C. J., \& Mossberger, K. (2006). The Effects of E-Government on Trust and Confidence in Government. Public Administration Review, 66(3), 354-369.

Trudeau, L. (2009). Summary Analysis of the Open Government Brainstorm. Retrieved September 20, 2013, from http://www.whitehouse.gov/files/documents/ostp/opengov_inbox/NAPA_analysis.pdf

U.S. Government Accountability Office. (2010). Challenges In Federal Agencies' Use of Web 2.0 Technologies. (GAO-10872T ). Washington, DC: Government Accountability Office.

U.S. Government Accountability Office. (2011). Grants.gov: Additional Action Needed to Address Persistent Governance and Funding Challenges. (GAO-11-478). Washington, DC: Government Accountability Office. 
UK Comptroller and Auditor General. (2012). Implementing Transparency: Cross-Government Review. Retrieved September 20, 2013, from http://www.official-documents.gov.uk/document/hc1012/hc18/1833/1833.pdf

Van Den Broek, T., Kotterink, B., Huijboom, N., Hofman, W., \& Van Grieken, S. (2011). Open Data Need A Vision Of Smart Government: Roadblocks To A Pan European Market For PSI Reuse. TNO (Netherlands Organisation for Applied Scientific Research).

Wadhwa, V. (2011, June 22). The death of open government. The Washington Post. Retrieved September 20, 2013, from http://www.washingtonpost.com/national/on-innovations/the-coming-death-of-opengovernment/2011/06/21/AGPK3afH_story.html?wpisrc=nl_cuzheads

Wonderlich, J. (2011, December 7). Obama's Open Government Directive, Two Years On. Sunlight Foundation. Retrieved September 20, 2013, from http://sunlightfoundation.com/blog/2011/12/07/obamas-open-government-directive-twoyears-on/

Yu, H., \& Robinson, D. (2012). The New Ambiguity of "Open Government”. UCLA Law Review Discourse, 178, 178-208.

Zuiderwijk, A., Janssen, M., Choenni, S., Meijer, R., \& Alibaks, R. S. (2012). Socio-technical Impediments of Open Data. Journal of e-Government, 10(2), 156-172.

About the Author

Alon Peled

Alon Peled is a Senior Lecturer in the Department of Political Science at the Hebrew University of Jerusalem, Israel. Alon studies information flows within the public sectors of large, democratic, and federated countries. He develops theoretical models and software to commoditize information as a contested commodity to improve information sharing in the public sector. Alon can be contacted via Alon.Peled@post.harvard.edu. 